\title{
EVALUATION OF THE FACIAL SOFT TISSUE CHANGES IN SKELETAL ANTERIOR OPEN BITE PATIENTS TREATED WITH RAPID MOLAR INTRUDER APPLIANCE USING CONE BEAM COMPUTED TOMOGRAPHY
}

\author{
Ahmed Sh. Hashem*, Shareef Alhindi** and Wael M. Refai***
}

\begin{abstract}
Aim: The aim of this study was to evaluate the facial soft tissue changes in skeletal anterior open bite patients treated with rapid molar intruder appliance using cone beam computed tomography (CBCT).

Materials and Methods: This retrospective study included 2 groups. The first treatment group included randomly selected CBCT scans of 20 skeletal open bite patients ( 8 males and 12 females, mean age 11.6 \pm 1.1 years) who were treated with the rapid molar intruder appliance (RMI) for molar intrusion. The CBCT scans were taken before treatment (T1) and after open bite correction (T2). The facial soft tissue changes in the treatment group were compared with a closely matched second untreated control group with normal anterior overbite ( 9 males and 11 females, mean age $11.9 \pm 1.2$ years).
\end{abstract}

Results: The first group showed significantly greater decreases in the angle of facial convexity and the $\mathrm{H}$ angle than the second group. The first group showed significantly greater increases in the lower lip protrusion and the soft tissue chin prominence than the second group. The upper lip protrusion and the soft tissue facial height were decreased in the first group and increased in the second one. The difference was statistically significant. The nasolabial angle was increased in the first group and decreased in the second one. The difference was statistically significant.

Conclusions: Molar intrusion using the rapid molar intruder appliance (RMI) could result in significant improvement in the facial soft tissue profile in skeletal anterior open bite patients.

KEY WORDS: Skeletal anterior open bite, Rapid molar intruder appliance, Facial soft tissue profile, Cone beam computed tomography.

\footnotetext{
* Lecturer of Orthodontics, Faculty of Dentistry, Minia University.

** Researcher in Department of Orthodontics, Faculty of dentistry, Minia University.

*** Professor of Orthodontics, Faculty of dentistry, Minia University.
} 


\section{INTRODUCTION}

Anterior open bite has been believed as a major challenging problem during orthodontic therapy. ${ }^{1,2}$ This malocclusion could result from combined impacts of skeletal, dental, respiratory, neurologic, and habitual factors. ${ }^{3}$ The multifactorial nature of this malocclusion necessitates appropriate detection and removal of the etiologic factors, careful diagnosis and suitable treatment planning. ${ }^{4}$ Anterior teeth extrusion ${ }^{5,6}$ or molar intrusion ${ }^{7,8}$ could be possible treatment options for correction of anterior open bite cases.

Skeletal anterior open bite patients usually have excessive anterior facial height, reduced posterior facial height, Class II tendency, enlarged gonial angle, excessive mandibular plane angle, and pronounced antegonial notching. ${ }^{9-11}$ Treatment of skeletal open bite by extrusion of anterior teeth could not diminish the enlarged anterior facial height, as the maloccusion has been mainly concealed by the extrusion of anterior teeth instead of intrusion of posterior teeth. ${ }^{12}$

Treatment possibilities that could provide an efficient solution for this problem by posterior teeth intrusion include high-pull headgear ${ }^{13}$, bite blocks, ${ }^{14}$ functional appliances,,$^{15}$ repelling magnets,,$^{16}$ miniscrews, ${ }^{17}$ miniplates ${ }^{12,19}$ and the rapid molar intruder appliance (RMI). ${ }^{6,19}$

Repelling magnets could offer problematic three dimensional control during molar intrusion as they may shift from their centered contact with subsequent development of crossbite. ${ }^{20}$ Although miniscrews and miniplates could produce effectual molar intrusion without dependence on patient cooperation, ${ }^{17,19}$ their expense and the resulting discomfort should be considered..$^{21}$

RMI is a fixed appliance that is not reliant on a superior level of unexpected patient compliance as high-pull headgear, bite blocks and functional appliances. $^{21}$ It is able to provide continuous intrusive forces on both maxillary and mandibular molars. ${ }^{21,23}$ In addition to the noticeable levels of patient acceptance and hygienic benefits, it can be easily combined with fixed appliances. ${ }^{21}$

Ideal occlusion, facial esthetics or both may be the reason for requesting orthodontic therapy and they are well known as parallel intentions of orthodontic treatment. ${ }^{24}$ The influences of various treatment alternatives on the facial soft tissues are of primary concern to most patients. ${ }^{25}$ The response of soft tissue profile to orthodontic tooth movement is greatly changeable. ${ }^{26}$

Although several previous studies assessed the dental and skeletal effects of RMI, ${ }^{6,21-23}$ no studies to the best of our knowledge discussed its impacts on the facial soft tissue. Therefore, the aim of this study was to evaluate the facial soft tissue changes in skeletal anterior open bite patients treated with rapid molar intruder appliance using cone beam computed tomography.

\section{MATERIALS AND METHODS:}

Approval concerning the ethical aspects of this study protocol was attained by the ethical committee of the Faculty of Dentistry, Minia University. Sample size was settled ${ }^{27}$ relying on a pilot study on 8 randomly selected cone beam computed tomographic scans (CBCT) scans for patients treated from skeletal anterior open bite using the rapid molar intruder appliance (RMI). The effect size for the angle of facial convexity was $1.4^{\circ} \pm 1.35^{\circ}$. With a significance level of 0.05 and a power of study $90 \%$, the study included 20 patients in every group.

The study group consisted of randomly selected pre-treatment (T1) and post-open bite correction (T2) CBCT scans of 20 subjects (8 males and 12 females, mean age 11.6 \pm 1.1 years). The inclusion criteria comprised:

1- Skeletal anterior open bite with mandibular plane angle (SN/MP) more than 36 . 
2- No preceding orthodontic therapy.

3- Free of active periodontal disease.

4- Free of systemic diseases.

Another untreated control group included 20 subjects of equivalent age and sex to the first group with normal anterior overbite ( 9 males and 11

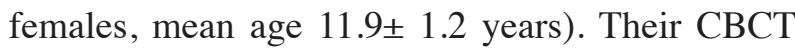
scans were formerly rendered for purposes like identifying impacted teeth, evaluation of the bone height or upcoming orthodontic therapy.

All patients of the study group were treated by the same operator in the department of orthodontics, Faculty of Dentistry, Minia University using the RMI appliance (American Orthodontics, Sheboygan, Wis).

The RMI appliance had one elastic spring module on each side that was attached to orthodontic bands on maxillary and mandibular first molars. The terminal ends of the modules were attached with L-shaped ball pin connectors that were engaged into the buccal tubes welded to orthodontic bands (Figure 1). The maxillary tube received a straight endcap, while the mandibular tube got an angulated one. Maxillary and mandibular first molars were stabilized by using transpalatal and lingual holding arches respectively.

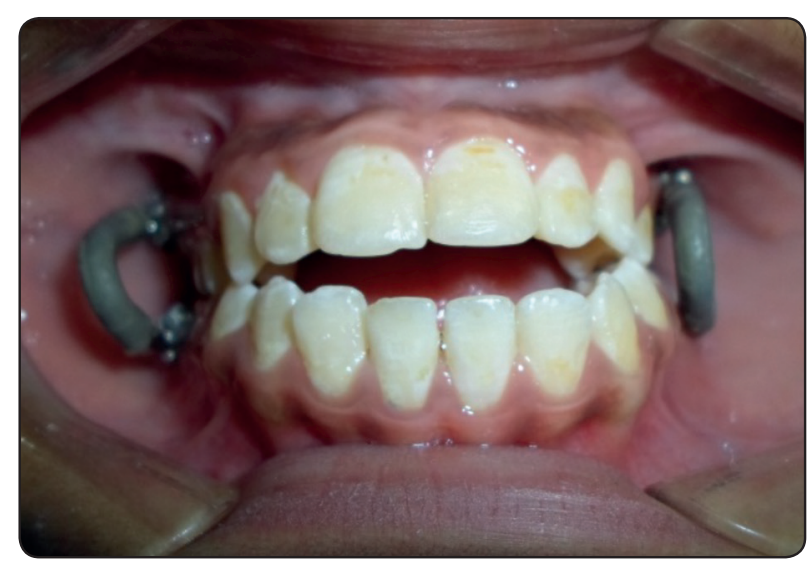

Fig. (1) RMI attached to maxillary and mandibular first molar bands.
As the patient was closing the jaws, the intrusion force resulting from the flexion of the elastic modules was transmitted to the maxillary and mandibular first molars.

Follow-up visits were every 3 weeks to evaluate the treatment progress and check the oral hygiene measures. The treatment was continued until the anterior open bite was corrected.

CBCT scans (Scanora 3Dx Soredex, Finland) were obtained using the same standard method at $10 \mathrm{~mA}$ and $90 \mathrm{kV}$. Data were then exported and shifted to DICOM format (Digital Imaging and Communications in Medicine) with i-CAT software (Hatfield, Pennsylvania, USA). An entirely restructured 3 dimensional image was obtained by using the Mimics image processing software (Materialise Group, Leuven, Belgium).

Distinguishing the landmarks was achieved depending on the generated multiplanar projections. The elected points were subsequently verified on the 3 dimensional images and the software was utilized to calculate various measurements (Figure 2). Tables 1 and 2 show the landmarks and measurements used in this study.

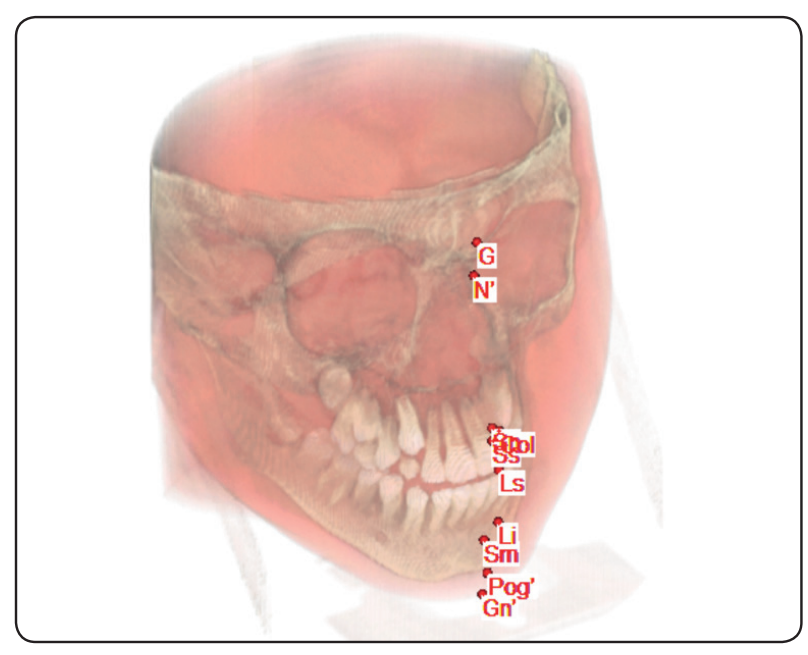

Fig. (2) Determination of the landmarks on the multiplanar projection of CBCT. 
TABLE (1) CBCT three dimensional reference landmarks

\begin{tabular}{|l|l|}
\hline Point & Definition \\
\hline Sella (S) & The point at the center of the sella turcica \\
\hline Glabella (G) & $\begin{array}{l}\text { The most protruded point on the soft tissue } \\
\text { anatomy of the forehead }\end{array}$ \\
\hline $\begin{array}{l}\text { Soft tissue } \\
\text { Nasion (N') }\end{array}$ & $\begin{array}{l}\text { The innermost point on the concavity } \\
\text { extending between the soft tissue outlines } \\
\text { of the head and the nose }\end{array}$ \\
\hline Subnasale (Sn) & $\begin{array}{l}\text { The point of union of the bottom of the } \\
\text { columella with the upper lip }\end{array}$ \\
\hline Columella (Col) & $\begin{array}{l}\text { The point of curvature of the base of the } \\
\text { nose at the inferior end of the nasal septum }\end{array}$ \\
\hline $\begin{array}{l}\text { Labrale } \\
\text { Superius (Ls) }\end{array}$ & $\begin{array}{l}\text { The anteriormost point on the upper lip } \\
\text { convexity }\end{array}$ \\
\hline Subspinale (Ss) & $\begin{array}{l}\text { The most concave point on the concavity } \\
\text { between the subnasale (Sn) and the labrale } \\
\text { superius (Ls) }\end{array}$ \\
\hline $\begin{array}{l}\text { Labrale Inferius } \\
\text { (Li) }\end{array}$ & $\begin{array}{l}\text { The anteriormost point on the lower lip } \\
\text { convexity }\end{array}$ \\
\hline $\begin{array}{l}\text { Soft tissue } \\
\text { Pogonion } \\
\text { (Pog') }\end{array}$ & $\begin{array}{l}\text { The most anterior point at the soft tissue } \\
\text { outline of the chin }\end{array}$ \\
\hline Gnathion (Gn') & $\begin{array}{l}\text { The most anterior inferior point on the soft } \\
\text { tissue outline of the chin } \\
\text { soft tissue pogonion (Pog') }\end{array}$ \\
\hline Soft tissue
\end{tabular}

TABLE (2) CBCT soft tissue angular and linear measurements

\begin{tabular}{|l|l|}
\hline \multicolumn{1}{|c|}{ Measurement } & \multicolumn{1}{c|}{ Definition } \\
\hline Protrusion of the upper lip & The angle S- N'-Ss \\
\hline Protrusion of the lower lip & The angle S- N'-Sm \\
\hline $\begin{array}{l}\text { Soft tissue facial convexity } \\
\text { angle }\end{array}$ & The angle G-Sn-Pog' \\
\hline H angle & The angle N'-Pog' -Ls \\
\hline Nasolabial angle & The angle Col -Sn- Ls \\
\hline Soft tissue chin prominence & The angle S-N'- Pog' \\
\hline Soft tissue facial height & $\begin{array}{l}\text { The distance between N'and } \\
\text { Gn' }\end{array}$ \\
\hline
\end{tabular}

\section{Error of the method}

The whole landmarks were relocated and the whole measurements were repeated by the same examinerthree times with two weeks interval between each of them. Cronbach's Alpha was calculated to estimate the reliability of measurements.

\section{Statistical method}

The gathered data were statistically analyzed using SPSS program (Statistical Package for Social Science version 20; IBM Corp., Armonk, N.Y). Shapiro-Wilk test illustrated normal distribution of all variables ( $\mathrm{P}>0.05$ for all of them). Descriptive statistics were done for quantitative data by mean \pm standard deviation. Analyses were done between both groups for parametric quantitative data using independent T-test and for qualitative data using Chi square test (expected number per cell $>5$ ). The level of significance was taken at $\mathrm{P}$ value $<0.05$.

\section{RESULTS}

Cronbach's Alpha exceeded 0.9 for all measurements in both groups denoting excellent method reliability. Chi square test revealed insignificant difference in sex distribution between both groups (P value $=0.102)$. Independent samples T-test revealed insignificant difference in age distribution between both groups $(\mathrm{P}$ value $=0.263)$.

Zero overbite was accomplished in all subjects of the first group. The mean treatment duration was $4.6 \pm 0.5$ months. Table 3 shows the descriptive statistics of different variables at $\mathrm{T} 1$ and the differences between $\mathrm{T} 1$ and $\mathrm{T} 2$ in both groups.

Upper lip protrusion was decreased after treatment in the first group (T2-T1 $=-0.7 \pm 0.4^{\circ}$ ), while it was increased in the second group (T2$\left.\mathrm{T} 1=0.1^{\circ} \pm 0.1\right)$. The difference was statistically significant between both groups ( $\mathrm{P}$ value $<0.001$ ) Lower lip protrusion was increased between $\mathrm{T} 1$ and $\mathrm{T} 2$ in the both groups (T2-T1 $=1^{\circ} \pm 0.4^{\circ}$ and 0.3 $\pm 0.1^{\circ}$ respectively. The difference was statistically 
significant between both groups (P value $<0.05)$.

The angle of facial convexity was more significantly decreased between $\mathrm{T} 1$ and $\mathrm{T} 2$ in the first than the second group (T2-T1 $=-2.7^{\circ} \pm 1^{\circ}$ and $-0.5^{\circ} \pm 0.3^{\circ}$ respectively with $\mathrm{P}$ value $\left.<0.01\right)$. The $\mathrm{H}$ angle was more significantly decreased between $\mathrm{T} 2$ and $\mathrm{T} 1$ in the first than the second group (T2-T1=$1.9^{\circ} \pm 0.8^{\circ}$ and $-0.2^{\circ} \pm 0.2^{\circ}$ respectively with $\mathrm{P}$ value $<$ $0.001)$.

The nasolabial angle was increased after treatment in the first group ( $\left.\mathrm{T} 2 \mathrm{~T} 1=1.6^{\circ} \pm 0.5^{\circ}\right)$, while it was decreased in the second group (T2-T1=-0.1 $\left.\pm 0.1^{\circ}\right)$. The difference was statistically significant between both groups ( $\mathrm{P}$ value $<0.001)$.

The soft tissue chin prominence was increased between $\mathrm{T} 2$ and $\mathrm{T} 1$ in the both groups (T2-T1=1.4 $\pm 0.7^{\circ}$ and $0.3^{\circ} \pm 0.1^{\circ}$ respectively). The difference was statistically significant between both groups ( $\mathrm{P}$ value $<0.01)$. The soft tissue facial height was decreased after treatment in the first group (T2$\mathrm{T} 1=-2.8 \mathrm{~mm} \pm 1.1 \mathrm{~mm}$ ), while it was increased in the second group $(\mathrm{T} 2-\mathrm{T} 1=0.9 \mathrm{~mm} \pm 0.5 \mathrm{~mm})$. The difference was statistically significant between both groups (P value $<0.001)$.

\section{DISCUSSION}

Non growing patients with skeletal open bite malocclusion can be idyllically treated with a combined orthodontic and orthognathic surgical approaches. ${ }^{28}$ The relapse tendency following this combined approach is frequently reduced compared with that perceived with nonsurgical treatment only. ${ }^{29}$

On the contrary, early correction of these cases can eradicate the hazards related to the orthognathic intervention and enhance the child's self-esteem by enhancing the facial appearance..$^{30}$ When the treatment of such cases is initiated with RMI in the permanent dentition stage, the only benefit is the possibility of combining the RMI and fixed appliance therapy with simultaneous alignment of both maxillary and mandibular arches. ${ }^{6}$

This study assessed the facial soft tissue changes resulting from intrusion of maxillary molars utilizing rapid molar intruder appliance in the management of skeletal anterior open bite patients. Transpalatal and lingual holding arches were utilized to stabilize maxillary and mandibular first molars respectively. Once the patient bites, the elastic modules are

TABLE (3) Three dimensional cephalometric measurements before treatment and comparison of the treatment changes between both groups

\begin{tabular}{|l|c|c|c|c|c|}
\hline & T1(Group 1) & T1 (Group 2) & T2-T1 (Group 1) & T2-T1 (Group 2) & P value \\
\hline Upper lip protrusion & $93.4 \pm 2.1$ & $92.5 \pm 1.9$ & $-0.7 \pm 0.4$ & $0.1 \pm 0.1$ & $<0.001^{*}$ \\
\hline Lower lip protrusion & $84.8 \pm 3.2$ & $83.6 \pm 3.5$ & $1 \pm 0.4$ & $0.3 \pm 0.1$ & $<0.05^{*}$ \\
\hline Angle of facial convexity & $19.1 \pm 4.6$ & $18 \pm 4$ & $-2.7 \pm 1$ & $-0.5 \pm 0.3$ & $<0.01^{*}$ \\
\hline H angle & $9.2 \pm 1.1$ & $8.3 \pm 0.9$ & $-1.9 \pm 0.8$ & $-0.2 \pm 0.2$ & $<0.001^{*}$ \\
\hline Nasolabial angle & $110.1 \pm 2.8$ & $110.6 \pm 2.3$ & $1.6 \pm 0.5$ & $-0.1 \pm 0.1$ & $<0.001^{*}$ \\
\hline Prominence of the soft tissue chin & $85.6 \pm 2.4$ & $84.5 \pm 2.9$ & $1.4 \pm 0.7$ & $0.3 \pm 0.1$ & $<0.01^{*}$ \\
\hline Soft tissue facial height & $98.7 \pm 3.2$ & $99.5 \pm 2.6$ & $-2.8 \pm 1.1$ & $0.9 \pm 0.5$ & $<0.001^{*}$ \\
\hline
\end{tabular}

Parametric quantitative data expressed as mean $\pm S D$.

Independent samples T-test for parametric quantitative data between both groups. 
activated to yield 600-900 grams of intrusive forces on the molars at each side. ${ }^{21}$ The anticipated buccal tipping of the molar crowns necessitates the application of transpalatal and lingual holding arches for support. ${ }^{21}$

In this study, the angle of facial convexity was more significantly decreased between $\mathrm{T} 1$ and $\mathrm{T} 2$ in the first than the second group (T2-T1 $=2.7 \pm 1^{\circ}$ and 0.5 ${ }^{\circ} \pm 0.3^{\circ}$ respectively with $\mathrm{P}$ value $\left.<0.01\right)$. Xun et al. ${ }^{31}$ reported a decrease in the facial soft tissue convexity by $1.9^{\circ}$ when self-drilling miniscrew implants were placed in the posterior midpalatal region and the buccal alveolar bone between the lower molars for treating open bite cases. Marzouk et al. showed reduction of facial soft tissue convexity by $2.3^{\circ} 7$ when adult skeletal anterior open bite patients were treated with zygomatic miniplates and by $3.92^{\circ} 32$ following maxillary posterior teeth intrusion using zygomatic miniplates and premolar extractions. Deguchi et al ${ }^{33}$ reported a significant decrease of the soft facial convexity angle by $6^{\circ}$ after implantanchored molar intrusion.

In our study, the nasolabial angle was increased after treatment in the first group (T2-T1 $=1.6^{\circ} \pm 0.5$ 9 , while it was decreased in the second group (T2$\left.\mathrm{T} 1=-0.1^{\circ} \pm 0.1^{\circ}\right)$. The difference was statistically significant between both groups ( $\mathrm{P}$ value $<0.001)$. Marzouk et al..$^{32}$ showed that intruding maxillary posterior teeth utilizing zygomatic miniplates accompanied by premolar extractions resulted in significant reduction in the nasolabial angle $\left(3.5^{\circ} \pm 0.9^{\circ}, \mathrm{P}\right.$ value $\left.\leq 0.01\right)$. Deguchi et al..$^{33}$ reported that implant-anchored maxillary molar intrusion resulted in insignificant increase in the nasolabial angle.

The soft tissue chin prominence was increased between $\mathrm{T} 1$ and $\mathrm{T} 2$ in the both groups (T2-T1=1.4 $\pm 0.7^{\circ}$ and $0.3^{\circ} \pm 0.1^{\circ}$ respectively). The difference was statistically significant between both groups (P value $<0.01)$. The soft tissue facial height was decreased after treatment in the first group (T2-
$\mathrm{T} 1=-2.8 \mathrm{~mm} \pm 1.1 \mathrm{~mm}$ ), while it was increased in the second group (T2-T1=0.9 $\mathrm{mm} \pm 0.5 \mathrm{~mm}$ ). The difference was statistically significant between both groups ( $\mathrm{P}$ value $<0.001)$. Molar intrusion or restriction of vertical growth at posterior dentoalveolar regions resulted in counterclockwise rotation of the mandible. ${ }^{6}$ Such rotation can interpret this significant effect on the soft tissue chin prominence and the soft tissue facial height.

Various previous studies utilized two dimensional lateral cephalometric radiographs to assess the dental, skeletal and soft tissue effects of molar intrusion..$^{21-23,31-33}$ Flaws in these two dimensional radiograms could develop as consequences to inappropriate patient positioning, challenging recognition of landmarks and imprecise linear and angular measurements. ${ }^{34}$ Depending on CBCT in this study could present an opportunity to overwhelm to a great extent the constraints associated with landmark detection, positioning errors and superimpositions in lateral cephalometric radiographs via image manipulation. ${ }^{35}$

\section{CONCLUSION}

Skeletal anterior open bite patients displayed significant improvement in the facial soft tissue profile after molar intrusion with the rapid molar intruder appliance.

\section{REFERENCES}

1. Burford D, Noar JH. The causes, diagnosis and treatment of anterior open bite. Dent Update 2003 Jun;30:235-41 .

2. Tavares CA, Allgayer S. Open Bite in Adult Patients. Dental Press J Orthod. 2019 Nov 11;24(5):69-78

3. Ngan P, Fields HW. Open bite: a review of etiology and management. Pediatr Dent. Mar-Apr 1997;19(2):91-8.

4. Insoft MD, Hocevar RA, Gibbs CH. The nonsurgical treatment of a Class II open bite malocclusion. Am J Orthod Dentofacial Orthop. 1996;110:598-605.

5. Endo T, Kojima K, Kobayashi Y, Shimooka S. Cephalometric Evaluation of Anterior Open-Bite Nonextraction 
Treatment, Using Multiloop Edgewise Archwire Therapy. Odontology. 2006 Sep;94(1):51-8.

6. Küçükkeleş N, Acar A, Demirkaya AA, Evrenol B, Enacar A. Cephalometric evaluation of open bite treatment with NiTi arch wires and anterior elastics. Am J Orthod Dentofacial Orthop 1999 Nov;116(5):555-62.

7. Cinsar A, Alagha AR, Akyalçin S. Skeletal Open Bite Correction with Rapid Molar Intruder Appliance in Growing Individuals. Angle Orthod. 2007 Jul;77(4):632-9.

8. Marzouk ES, Abdallah EM, El-Kenany WA. Molar intrusion in open-bite adults using zygomatic miniplates. Int $\mathrm{J}$ Orthod Milwaukee. 2015;26(2):47-54.

9. Nahoum HI, Horowitz SL, Benedicto EA. Varieties of anterior open bite. Am J Orthod. 1972;61(5):486-92.

10. Cangialosi TJ. Skeletal morphologic features of anterior open bite. Am J Orthod. 1984 Jan;85(1):28-36.

11. Klocke A, Nanda RS, Kahl-Nieke B. Anterior open bite in the deciduous dentition: longitudinal follow-up and craniofacial growth considerations. Am J Orthod Dentofacial Orthop. 2002 Oct;122(4):353-8.

12. Sherwood KH, Burch JG, Thompson WJ. Closing anterior open bites by intruding molars with titanium miniplate anchorage. Am J Orthod Dentofacial Orthop 2002 Dec;122(6):593-600.

13. Lopez-Gavito G, Wallen TR, Little RM, Joondeph DR. Anterior openbite malocclusion: longitudinal 10-year postretention evaluation of orthodontically treated patients. Am J Orthod. 1985; 87:175-86.

14. Kuster R, Ingervall B. The effect of treatment of skeletal open bite with two types of bite-blocks. Eur J Orthod. 1992; 14(6):489-99.

15. Fränkel R, Fränkel C. A functional approach to treatment of skeletal open bite. Am J Orthod Dentofacial Orthop. 1983; 84(1):54-68.

16. Dellinger EL, Dellinger EL. Active vertical corrector treatment- long term follow-up of anterior open bite treated by the intrusion of posterior teeth. Am J Orthod Dentofacil Orthop. 1996;110(2):145-54.

17. Kuroda S, Katayama A, Takano-Yamamoto T. Severe anterior open-bite case treated using titanium screw anchorage. Angle Orthod. 2004;74(4):558-67.

18. Marzouk ES, Kassem HE. Evaluation of long-term stability of skeletal anterior open bite correction in adults treated with maxillary posterior segment intrusion using zygomatic miniplates. Am J Orthod Dentofacial Orthop. 2016;150(1):78-88

19. Albogha MH, Takahashi I, Sawan MN. Early treatment of anterior open bite: Comparison of the vertical and horizontal morphological changes induced by magnetic biteblocks and adjusted rapid molar intruders. Korean J Orthod. 2015;45(1):38-46.

20. Darendeliler M, Yüksel S, Meral O. Open-bite correction with the magnetic activator device IV. J Clin Orthod. 1995;29(9):569-76.

21. Carano A, Siciliani G, Bowman SJ. Treatment of Skeletal Open Bite with a Device for Rapid Molar Intrusion: A Preliminary Report. Angle Orthod. 2005;75(5):736-46.

22. Carano A, Machata WC. A rapid molar intruder for 'noncompliance' treatment. J Clin Orthod. 2002;36(3):137-42.

23. Carano A, Machata W, Siciliani G. Noncompliant treatment of skeletal open bite. Am J Orthod Dentofacial Orthop. 2005;128(6):781-86.

24. Tindlund RS, Rygh P. Soft-tissue profile changes during widening and protraction of the maxilla in patients with cleft lip and palate compared with normal growth and development. Cleft Palate Craniofac J. 1993;30(5):454-468.

25. Hayashida H, Ioi H, Nakata S, Takahashi I, Counts AL. Effects of retraction of anterior teeth and initial soft tissue variables on lip changes in Japanese adults. Eur J Orthod. 2011;33(4):419-26.

26. Kasai K. Soft tissue adaptability to hard tissues in facial profiles. Am J Orthod Dentofacial Orthop. 1998; 113(6):674-84.

27. Pandis N. Sample calculations for comparison of 2 means. Am J Orthod Dentofacial Orthop. 2012;141(4):519-21.

28. Solano-Hernández B, Antonarakis GS, Scolozzi P, Kiliaridis S. Combined Orthodontic and Orthognathic Surgical Treatment for the Correction of Skeletal Anterior OpenBite Malocclusion: A Systematic Review on Vertical Stability J Oral Maxillofac Surg. 2013;71(1):98-109.

29. Denison TF, Kokich VG, Shapiro PA. Stability of maxillary surgery in open bite versus nonopen bite malocclusions. Angle Orthod. 1989;59(1):5-10.

30. English JD. Early treatment of skeletal openbite malocclusions. Am J Orthod Dentofacial Orthop. 2002; 121(6): 563-65. 
31. Xun C, Zeng X, Wang X. Microscrew anchorage in skeletal anterior open-bite treatment. Angle Orthod. 2007;77(1): 47-56.

32. Marzouk ES, Kassem HE. Long-term stability of soft tissue changes in anterior open bite adults treated with zygomatic miniplate-anchored maxillary posterior intrusion. Angle Orthod. 2018;88(2):163-70.

33. Deguchi T, Kurosaka H, Oikawa H, et al. Comparison of orthodontic treatment outcomes in adults with skeletal open bite between conventional edgewise treatment and implant-anchored orthodontics. Am J Orthod Dentofacial Orthop. 2011;139(4 Suppl):S60-S68.

34. Chen YJ, Chen SK, Yao JC, et al. The effects of differences in landmark identification on the cephalometric measurements in traditional versus digitized cephalometry. Angle Orthod. 2004;74(2):155-161.

35. Shaw K, McIntyre G, Mossey P, et al. Validation of conventional 2D lateral cephalometry using $3 \mathrm{D}$ cone beam CT. J Orthod. 2013;40(1):22-29. 